an objective remission in one patient who underwent hormonal ablation and was shown to be ER-negative, PgR-positive.

I hope that the above-cited references will correct the impression that only ER-positive tumours contain $\mathrm{PgR}$. Although the number of cases of PgR-positive, ER-negative tumours is small, they do exist. The importance of recognising this group of mammary carcinomas is that it may provide new insights into the interrelationship that exists between various hormones, their receptors, and tumour regression.

JEROME APPELBAUM

Department of Medicine,

Maimonides Medical Center,

Brooklyn, New York

Raynaud, J P, fournal of Steroid Biochemistry, 1975 14, 6. 37,464

Tobin, E H, et al, in Multiple Molecular Forms of Steroid Hormone Receptors, ed M K Agarwal, p 181 Amsterdam, Elsevier/North-Holland Biomedical

McGuire, W L, Horowitz, K B, and DeLaGarza, M in Cancer: Trends in Research and Treatment, ed C Heuson, W $H$ Mattheim, and $M$ Rozencweig, p 181. New York, Raven Press, 1976.

Degenshein, G A, et al, Breast, 1977, 3, 29.

Horowitz, K B and McGuire, W L, in Progesterone Receptors in Normal and Neoplastic Tissue, ed W I McGuire, J P Raynaud, and E E Baulieu, p 102 New York, Raven Press, 1977

King, R J B, First Innsbruck Winter Conference on Biochemistry in Clinical Medicine, Innsbruck, Austria, January 1978

Bloom, N, Tobin, E H, and Degenshein, G A, in Progesterone Receptors in Normal and Neoplastic Tissue, ed W L McGuire, J P Raynaud, and

**We would agree that the statement that progesterone receptors occur only in patients who are ER-positive is too absolute. As $\mathrm{Dr}$ Appelbaum points out, PgR have been reported in a few ER-negative patients, though it is of interest that there is a clear relationship between the concentrations of oestrogen and progesterone receptors even in those patients who are reported as receptorpositive. ${ }^{1-3}$ Clinical studies of hormone responsiveness in this small group of patients will be required before the meaning and relevance of such a finding are evident.-ED, BMf.

${ }^{1}$ Pichon, M F, and Milgram, E, Cancer Research, 1977, 37, 464

Horowitz, K B, and McGuire, W L, in Progesteron Receptors in Normal and Neoplastic Tissue, ed W L McGuire, J P Raynaud, and E E Baulieu, p 102 New York, Raven Press, 1977.

Leclercq, G, et al, in Progesterone Receptors in Normal and Neoplastic Tissue, ed W L McGuire, J P Raven Press, 1977.

\section{Thyroid function tests}

SIR, - We read with interest the comments of Mr M G Davies and Dr $H$ Allison and of Dr W A Burr (9 September, p 771) on our paper on thyroid function tests in patients with abnormal concentrations of thyroxinebinding proteins (12 August, $\mathrm{p} 477$ ).

We agree with Mr Davies and Dr Allison that the free thyroxine index (FTI), whether modified as we suggested or not, may be misleading in patients with very high concentrations of thyroxine-binding globulin (TBG) because of the limitations of the Thyopac-3 technique. ${ }^{1}$ To check whether erroneous high values influenced the normal range for our modification of the FTI we recalculated it using data from only those patients with Thyopac- 3 values of $120 \%$ or less. The $95 \%$ limits obtained using the data did not differ from those for all 200 patients. Thus our reference range remains valid. Their suggestion that a single zero standard will resolve the "zero error" in the conventional FTI is incorrect because of the spread of values at very low thyroxine (T4) and Thyopac- 3 values.

We suggested in our paper that further investigation is needed to determine whether the T4:TBG ratio or our modification of the FTI provides the better discriminant for the evaluation of thyroid function in patients with abnormal binding proteins. The original paper by Dr Burr and his colleagues ${ }^{1}$ gave data on patients with absent TBG but none on euthyroid patients with such conditions as nephrotic syndrome or chronic liver disease who have measurable TBG values below $5 \mathrm{mg} / \mathrm{l}$. In his letter Dr Burr gives the numbers of false-negative diagnoses for our modification of the FTI, the conventional FTI, and the T4:TBG ratio in 101 patients with thyrotoxicosis and 36 with myxoedema. He concludes that the modified FTI is "almost certainly inferior" to the T4:TBG ratio. However, the diagnostic efficiency of a test depends not only on the false-negative rate but also on the false-positive rate, and both are needed, particularly in patients with abnormal binding proteins, before conclusions can be drawn.

The first-line tests of thyroid function are commonly estimations of either total T4 and thyroid-stimulating hormone or total $\mathrm{T} 4$ and triiodothyronine, depending on the clinical situation. It may well be that in those patients in whom measurement of binding proteins is indicated the T4:TBG ratio will provide a better discriminant than our modification of the FTI. However, we believe that this remains to be proved.

P SHERIDAN

R B PAYNE

St James's University Hospital

${ }^{1}$ Burr, W A, et al, British Medical fournal, 1977, 1, 485.

Postpartum haemorrhage after induced and spontaneous labour

SIR,-Surgeon Commander P R S Brinsden and Mr A D Clark (23 September, p 855) may be interested in the results of an analysis I made into the relationship between the administration of oxytocics during labour and primary postpartum haemorrhage at this hospital during 1974.

Of the 907 deliveries occurring during that year, $49 \cdot 2^{\circ}$ o were induced and $54.1 \%$ were preceded by administration of an oxytocic to

Oxytocic administration and postpartum haemorrhage (No of cases)

\begin{tabular}{|c|c|c|c|c|c|c|}
\hline & \multicolumn{2}{|c|}{$\begin{array}{c}\text { Syntocinon } \\
\text { infusion }\end{array}$} & \multirow{2}{*}{$\begin{array}{c}\text { Buccal } \\
\text { oxytocin }\end{array}$} & \multirow{2}{*}{$\begin{array}{c}\text { Dinoprostone } \\
\text { oral } \\
\text { solution }\end{array}$} & \multicolumn{2}{|c|}{ No oxytocic } \\
\hline & $\begin{array}{l}\text { Primi- } \\
\text { gravidae }\end{array}$ & $\begin{array}{c}\text { Multi- } \\
\text { gravidae }\end{array}$ & & & $\begin{array}{c}\text { Primi- } \\
\text { gravidae }\end{array}$ & $\begin{array}{c}\text { Multi- } \\
\text { gravidae }\end{array}$ \\
\hline Total treated $\ldots$ & 164 & 143 & 130 & 54 & 144 & 272 \\
\hline $\begin{array}{l}\text { Simple postpartum } \\
\text { haemorrhage }\end{array}$ & 4 & 8 & 1 & 1 & 3 & 5 \\
\hline $\begin{array}{l}\text { Postpartum } \\
\text { haemorrhage and }\end{array}$ & & & & & & \\
\hline $\begin{array}{l}\text { forceps delivery } \\
\text { Postpartum }\end{array}$ & 3 & - & - & - & 4 & - \\
\hline $\begin{array}{l}\text { haemorrhage and } \\
\text { manual removal of }\end{array}$ & & & & & & \\
\hline$\underset{\text { potal postpartum }}{\text { placenta }} \ldots$ & 1 & 1 & 2 & - & - & 1 \\
\hline haemorrhage & 8 & $9^{*}$ & 3 & 1 & 7 & $6^{*}$ \\
\hline
\end{tabular}

$* \chi^{2}=3 \cdot 4: P<0 \cdot 10$ induce or accelerate labour. The incidence of primary postpartum haemorrhage, defined as a loss of $500 \mathrm{ml}$ or more within $24 \mathrm{~h}$ of delivery,

No relationship was apparent between oxytocin infusion and primary postpartum haemorrhage in primigravidae. In multigravidae, however, the relationship may have been clinically significant. The oxytocin regimen used was that described by Normington. ${ }^{1}$

Sheppey General Hospital,

Minster-on-Sea,

' Normington, E A M, fournal of Obstetrics and Gynaecology of the British Commonwealth, 1972,

SIR,-I am grateful for the study by Mr P R S Brinsden and Mr A D Clark (23 September, p 855) of the impact of induction of labour on the incidence of postpartum haemorrhage. Indeed, postpartum haemorrhage may be, and too often is, a complication of induced labour. However, one very simple measure-the continuation of the intravenous oxytocic infusion for, say, one hour after the delivery of the of labour coined by our USA colleagues) is supreme for the prevention of this complication. That hypotonic postpartum haemorrhage is indeed preventable has been clearly shown by our analysis of a consecutive series of about 1700 elective labour inductions by means of low amniotomy and intravenous oxytocin, prostaglandin $\mathrm{E}_{21}$ or prostaglandin $\mathrm{F}_{2} \alpha$.

\section{Michel Thiery}

Department of Obstetrics,

Academic Hospital,

Ghent,

\section{Radiology work load}

SIR,-The extraordinary response from Dr M Lea Thomas (2 September, p 706) to my paper on radiology work load (12 August, $\mathrm{p}$ 514) has deflected the debate from the central issue.

My objective is a system of radiological practice in which patients derive maximum benefit. My thesis is that each department has a capacity limited by the need to maintain reasonable professional standards. Where demand exceeds this reasonable capacity priorities are determined by consultation with users. Urgent work is done before less urgent, which may have to wait. The length of this wait will diminish if inappropriate requests are not initiated. Although this was as shown in the table below. placenta (the duration of the "fourth stage" 
discipline may evoke animosity towards the department, it is effective.

Dr J D Wigdahl's point (2 September, $p$ 707) about urgent general practitioner requests is taken. We now accept such requests if the urgent circumstances are outlined. The report copy and the letter are reviewed by the district medical committee to ensure that the facility is not regularly abused. I certainly do not wish GPs or anyone else to adopt a laissez faire attitude to disease. I hope no one else wants radiologists to develop a Lea Thomas attitude to organ-imaging.

M J BRINDLE

\begin{abstract}
West Norfolk and King's Lynn
\end{abstract} King's Lynn, Norfolk

\section{Dopamine and dobutamine}

SIR,-I was distressed to read the letter from Mr Alan Yates (17 June, p 1622) in which he grossly misquotes my paper. ${ }^{1} \mathrm{Mr}$ Yates writes that "dopamine is dependent for its effect on the release of myocardial noradrenaline,$^{1}$ while dobutamine is not." In the paper to which he refers I wrote, "Dopamine increases myocardial contractility and heart rate by direct action on $\beta$-adrenergic receptors. It also releases norepinephrine from myocardial catecholamine storage sites."

The primary difference in the haemodynamic action of dobutamine and dopamine, in my opinion, is not because of difference in direct or indirect action on the heart but because of difference in their vascular actions. ${ }^{2}$ In lower doses dopamine reduces blood pressure and total peripheral resistance, in part because of direct action on specific receptors which cause vasodilatation in the renal and mesenteric vascular beds. With slightly higher doses $\beta$-adrenergic receptors are activated to increase cardiac contractility and cardiac output. In this dose range dopamine has been used successfully for the treatment of refractory congestive heart failure. ${ }^{1-5}$ When the dose of dopamine is increased further $\alpha$-adrenergic vasoconstriction could occur which would be undesirable for treatment of congestive heart failure. On the other hand patients in shock may require the vasoconstricting action of dopamine to maintain adequate blood pressure. Recent studies have shown that vasodilators such as nitroprusside may be used in combination with dopamine to decrease vasoconstriction in patients with congestive heart failure. ${ }^{2} 6$

Dobutamine acts on $\beta_{1}$-adrenergic receptors and exerts relatively minor effects on $\alpha$ - and $\beta_{2}$-adrenergic receptors. Accordingly it can increase cardiac output and decrease total peripheral resistance over a wider dosage range than dopamine. In the official package insert dobutamine is recommended "for inotropic support in the treatment of heart failure. . . "Unlike dopamine it is not recommended for treatment of shock. Because dobutamine does not have the ability to increase peripheral resistance it could cause myocardial ischaemia if the heart were stimulated at a time when blood pressure was too low to maintain coronary blood flow.

Finally, $\mathrm{Mr}$ Yates states that "there are strong reasons to support the experimental evidence that the inotropic action of dobutamine does not produce expansion of myocardial ischaemia following infarction." In my opinion there are inadequate data to support this suggestion without a special precaution included in the package insert: "Particular care should be exercised when Dobutrex (dobutamine) is used in patients with acute myocardial infarction, especially with widespread coronary artery disease. . . " Dobutamine, dopamine, and all other sympathomimetic amines acting on the heart can increase the oxygen consumption of the myocardium with resultant arrhythmias or extension of the infarction unless myocardial oxygen consumption is simultaneously decreased by another mechanism such as reduction in heart size. ${ }^{7}$ We do not have sufficient knowledge to predict the effects of dobutamine on myocardial oxygen consumption in an individual patient with myocardial infarction.

LEON I GOLDBERG

$$
\begin{aligned}
& \text { Department of Pharmacological and } \\
& \text { Physiological Sciences, } \\
& \text { University of Chicago } \\
& \text { ' Goldberg, L I, New England fournal of Medicine, } \\
& \text { 1974, 291, 707. } \\
& \text { ' Goldberg, L I, Hsieh, Y-Y, and Resnekov, L, Progress } \\
& \text { in Cardiovascular Diseases, 1977, 19, 327. } \\
& \text { 'Goldberg, L I, McDonald, R H, jun, and Zimmerman, } \\
& \text { A M, New England fournal of Medicine, 1963, 268, } \\
& \text { 1060. } \\
& \text { ' Rosenblum, R, Tai, A R, and Lawson, D, fournal of } \\
& \text { Pharmacology and Experimental Therapeutics, 1972, } \\
& \text { 183, 256. } \\
& \text { 5urairaj, S K, and Haywood, L J, Clinical Phar- } \\
& \text { macology and Therapeutics, 1978, 24, 175. } \\
& \text { 'Miller, R R, et al, Circulation, 1977, 55, 881. } \\
& { }^{7} \text { Goldberg, L I, American fournal of Cardiology, 1968, } \\
& \text { 22, 177. }
\end{aligned}
$$

***We sent a copy of this letter to Mr Yates, whose reply is printed below-ED, $B M \mathcal{F}$.

SIR,-In reply to Dr Goldberg's letter I really feel it is not necessary to discuss the differences of opinion between us regarding the modes of action of dopamine and dobutamine, as the primary reason for my original communication was the confusion arising from the similarity between the names of these drugs. Dr Goldberg's letter underlines the fact that there are definite pharmacological differences between them. Furthermore, I certainly agree with $\mathrm{Dr}$ Goldberg that we do not yet have sufficient knowledge to predict or confidently define the exact modes of action of these two drugs. Their differing effects on the peripheral vascular resistance is, of course, an important point, and as cogent an argument can be made for reducing the peripheral resistance as raising it in conditions of low cardiac output. Certainly raising the peripheral vascular resistance is of great importance when it represents a risk of peripheral ischaemia and gangrene.

Alan Yates

Guy's Hospital,
London SE1

\section{Alpha-fetoprotein levels in cirrhosis and cancer of the liver}

SIR, - We have read with interest the report by Dr P J Johnson and others (2 September, p 661), though we think their results are rather surprisingly in contrast to those of other workers ${ }^{1-3}$ and our own findings.

In patients with cirrhosis of the liver without evidence of malignancy we found raised serum levels $(>20 \mathrm{mg} / \mathrm{ml})$ of $\alpha$-fetoprotein (AFP) in 80 out of 325 cases (26\%), although the levels were never higher than $300 \mathrm{ng} / \mathrm{ml}$. In 23 cases of primary liver cell cancer (PLC) arising in cirrhotic patients the concentration was higher than normal in 22 cases (95\%) (median $18567 \mathrm{ng} / \mathrm{ml}$ ). In 11 patients with PLC arising in normal liver AFP levels were abnormal in $10(90 \%)$ (median 35235$)$. Of the 22 cases of secondary liver tumours AFP concentrations were higher than $20 \mathrm{ng} / \mathrm{ml}$ in $10(45.4 \%$ ) (median $1650 \mathrm{ng} / \mathrm{ml}$ ).

In our experience, and in agreement with $\mathrm{Mr}$ Johnson and his colleagues, in most cases of PLC in cirrhotic patients the AFP level is high, but in contrast the level is also high in $90 \%$ of cases of PLC arising in normal livers and in a high proportion of cases of secondary liver deposits, while concentrations of AFP are raised in $26 \%$ of cirrhotics without evidence of malignancy, so that this finding does not permit the prediction of an ominous outcome. The work of Dr Johnson and his colleagues must be regarded with caution, at least in geographical areas other than Britain.

JAime Vilaseca Alvaro Ruibal JOSE MONNÉ

RICARDO BACARDI JAIME GUARDIA

Department of Medicine,

Nuclear Medicine Service,

Cocial,

Barcelona

1 Delmont, J, et al, Digestion, 1974, 10, 29.

${ }^{2}$ Rouslahti, E, and Seppala, M, Lancet, 1972, 2, 278.

\section{Behçet's disease}

SIR,-Although, as your leading article states (22 July, p 234), the exact aetiology of Behçet's disease remains unknown, it is clear that much of the diverse symptomatology is secondary to vasculitis. ${ }^{1}$ In addition there is often a defect in fibrinolysis ${ }^{2}$ with the development of venous thromboses and, as Dr R A C Graham-Brown has pointed out (19 August, p 570), treatment with ethyloestrenol and phenformin or with streptokinase has been shown to be of benefit. The anabolic steroid stanozolol has been shown to enhance fibrinolysis ${ }^{3}$ and to be of value in the treatment of both idiopathic recurrent thrombophlebitis ${ }^{4}$ and Raynaud's phenomenon. ${ }^{5}$ We should like to report the apparently successful use of this drug in a patient with Behçet's disease.

The patient, a 50-year-old Indian, was diagnosed as suffering from Behçet's disease in 1965 when oral and genital ulceration appeared. Subsequently he developed arthralgia and neurological symptoms and in June 1977 a deep-vein thrombosis in the left leg. Conventional therapy, including anticoagulation, did not prevent further extensive thrombotic episodes over the following six months. Investigations during this period revealed normal coagulation and platelet function studies but the resting fibrinolytic activity in his blood was reduced, as measured by a fibrin plate lysis area (FPLA) of between 25 and $40 \mathrm{~mm}^{2}$ (normal $80 \pm 40 \mathrm{~mm}^{2}$ ). In December 1977 treatment aimed at improving fibrinolysis with stanozolol $5 \mathrm{mg}$ twice daily was started. Therapy has now been continuous for nine months and during that time he has had no further thrombotic episodes, although oral and genital ulceration has persisted. After six months the resting fibrinolytic activity was reassessed and the FPLA had increased to $169 \mathrm{~mm}^{2}$.

The effectiveness of anabolic steroids in enhancing fibrinolysis is well recognised though their action is often short-lived. Resistance soon develops to ethyloestrenol given alone, although when phenformin is also given a sustained action is achieved. ${ }^{6} \mathrm{We}$ 